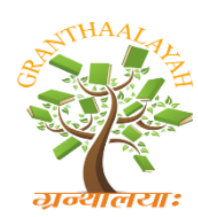

\author{
INTERNATIONAL JOURNAL OF RESEARCH - \\ GRANTHAALAYAH \\ A knowledge Repository
}

\title{
Social
}

\section{THE IMPACT OF EFFECTIVE TEACHING STRATEGIES ON PRODUCING FAST AND GOOD LEARNING OUTCOMES}

\author{
Ahmed Awad Amin Mahmoud Raba *1 \\ ${ }^{*}$ School of Education and Teacher Training, An-Najah National University/Palestine
}

DOI: https://doi.org/10.29121/granthaalayah.v5.i1.2017.1691

\begin{abstract}
This study aimed to find out the impact of effective teaching strategies on producing fast and good learning outcomes. It also aimed to determining the role of the study variables (the place graduation, the college where he taught in, the number of published research, the number of conferences and workshops, participation in the Good Samaritan program, teaching experience and academic rank) in producing fast and good Learning outcomes. To achieve these purposes, the researcher used a 25- item questionnaire distributed among lecturers at An-Najah National University. Additionally, the researcher interviewed five lecturers randomly selected from the same faculties at An-Najah National University as well.

The data were collected and analyzed using SPSS to answer the questions of the study. The researcher found out that there was positive impact of effective teaching strategies on producing good and fast learning outcomes. Also, the results showed that there were no statistical significant differences at $(\alpha=.05)$ in the impact of effective teaching strategies on producing fast and good learning outcomes due to the study variables. Based on these findings, the researcher recommended the lecturers to use effective teaching strategies via continual improvement and updating their teaching strategies.
\end{abstract}

Keywords: Impact; Effective Teaching Strategies; Learning Outcomes.

Cite This Article: Ahmed Awad Amin Mahmoud Raba. (2017). "THE IMPACT OF EFFECTIVE TEACHING STRATEGIES ON PRODUCING FAST AND GOOD LEARNING OUTCOMES." International Journal of Research - Granthaalayah, 5(1), 43-58. https://doi.org/10.29121/granthaalayah.v5.i1.2017.1691.

\section{Introduction and Theoretical Background}

What determines the kind of learning outcomes is the appropriate knowledge given to the students by a variety of pedagogies. From here, immerges the role of the teacher in selecting the best material and directing learners to the best trusted sources of knowledge. Because people are learning all the time, we need rubrics that can help educators distinguish between good and bad learning outcomes. Organizations and societies as well as the psychology of learning ask for new 
learning outcomes, new learning processes which are the results of new effective teaching pedagogies.

The results of effective teaching as described by educators and institution representatives refer to learning outcomes that are durable, flexible, functional, meaningful, generalizable and application-oriented. Furthermore, teaching effectively results in independent- learning, thinking, collaboration and regulation-skills. In order to be able to reach the results mentioned above, new kinds of teaching processes are needed: active, constructive, goal-directed, diagnostic, reflective, discovery oriented, contextual, problem oriented, case based, among others. Applying these teaching strategies appropriately requires well-trusted means of knowledge are needed and here the teacher's role appears.

Although many people believe that good teaching is impossible to define in any general way, a large body of research suggests that certain characteristics are consistently associated with good college teaching as viewed by students, other teachers, and administrators. In a study of winners of the Alumni Distinguished Teaching Award at Ohio State (Ebro, 1977). To the researchers' knowledge, observation of classes identified the following characteristics of effective teaching.

First, good teaching practices encourage cooperation among students, this principle deals with teaching practices which encourages cooperation among students. (Beishuizen, 2001) suggested to the teachers to encourage participation in classroom and to create effective asynchronous discussion. Second, good teaching practices encourage active learning, they support projectbased learning which determines that students learn valuable skills from seeing and doing. Third, good teaching practices provide the teacher with valuable feedback about students' progress; and accordingly can make amendment to improve students' learning.

Fourth, good teaching practices communicate high expectations, teachers should communicate high expectations for students' performance by giving them challenging assignments e.g. asking students to apply theories to real-world situations.

Fifth, good teaching practices take into consideration the students' learning styles and allow students to research their own issue of interest, instead of assigning particular issues. This encourages students to express their own diverse points of view. Instructors can provide guidelines to help students select topics relevant to the course while still allowing students to share their unique perspectives.

Sixth, good teaching practices respect commitment and punctuality. They began class promptly and were well organized. They taught at an appropriately fast pace, but stopped regularly to check students' comprehension and engagement.

Seventh, good teaching practices encourage rapport in the classroom with learners. Teachers praise students and provide warm classroom climate by allowing students to speak freely and express their opinions. Eighth, good teaching practices enhance self-confidence, (Eison, 1990), stresses the importance of confidence for new teachers which can be built upon good planning, clear goals, and a cultivation of relaxation and self-esteem. 
Ninth, good teaching practices helps to sustain growth in teaching by involving continuing to learn. (Chism, 1993), suggests that experienced teachers can avoid burn out and continue to improve through stimulating their own thinking by taking advantage of opportunities to learn new approaches for teaching and reflecting on their teaching continually and making changes based on those reflections.

It is concluded that effective teaching pedagogies can result in using the most beneficial kind of knowledge which in turns will achieve good and fruitful learning outcomes. Lack of effective education is one of the greatest barriers to success and achieve learning purposes, therefore, the researcher conducted this study to shed light on the importance of teaching strategies and their effects on the learning process.

\section{Statement of the Problem}

As the researcher works in the field of teaching, he noticed that students are slow learners and low achievers, this problem may occur as a result of many reasons, one of them is the teachers' teaching strategies. By reviewing the literature on the topic and visit some of the lecturers at the university through the sincere friend program, the researcher noticed that the practice of effective teaching at the university level in Palestine has not been studied and did not receive the attention of researchers in this area. This is what encourages the researcher to conduct this study to examine the impact of effective teaching strategies on producing good and fast learning outcomes.

\section{Purpose of the Study}

This study tries to achieve the following purposes:

- To examine the impact of effective teaching strategies on producing fast and good learning outcomes.

- It also seeks to identify the role of the study variables ( place of graduation, college where they taught in ,number of research, number of conferences and workshops , membership in Good Samaritan program, years of experience and academic rank ) on the impact of effective teaching strategies on producing fast and good learning outcomes .

\section{Importance of the Study}

This study is an important attempt because it deals with an important issue, which is teaching strategies and their effects on students' learning outcomes. It is also important because it gives useful information about the relation between teaching strategies and learning outcomes for the lecturers so they can take the study results into consideration when preparing for their teaching.

\section{Questions of the Study}

This study tries to answer the following questions:

5.1.What is the impact of effective teaching strategies on producing fast and good learning outcomes? 
5.2. Are there statistical significant differences at $(\alpha=.05)$ in the impact of effective teaching strategies on producing fast and good learning outcomes due to the place of graduation?

5.3. Are there statistical significant differences at $(\alpha=.05)$ in the impact of effective teaching strategies on producing fast and good learning outcomes due to the college he taught in?

5.4. Are there statistical significant differences at $(\alpha=.05)$ in the impact of effective teaching strategies on producing fast and good learning outcomes due to the number of research?

5.5. Are there statistical significant differences at $(\alpha=.05)$ in the impact of effective teaching strategies on producing fast and good learning outcomes due to the number of conferences and workshops?

5.6. Are there statistical significant differences at $(\alpha=.05)$ in the impact of effective teaching strategies on producing fast and good learning outcomes due to membership in good Samaritan program?

5.7. Are there statistical significant differences at $(\alpha=.05)$ in the impact of effective teaching strategies on producing fast and good learning outcomes due to years of experience?

5.8. Are there statistical significant differences at $(\alpha=.05)$ in the impact of effective teaching strategies on producing fast and good learning outcomes due to the academic rank?

\section{Limitations of the Study}

The study was conducted on a sample of the scientific and literary lecturers chosen randomly at An Najah National University during the second semester of the academic year 2015/2016.

\section{Definition of Terms}

7.1.Effective Teaching: Teaching that includes the cultivation of thinking skills, stimulating interest in the subject, and motivating students to learn. Weimer (2013)

7.2.Effective Teacher: He/ she is one who demonstrates “... closeness, warmth, and enthusiasm (immediacy) perceived physical and psychological closeness of the teacher to the student ..." (Walls et al., 2002:40). According to Beishuizen, 2001, the most important characteristics of the effective teacher are being skilled, knowledgeable and experienced

7.3.A Good Samaritan Program: It is a program which takes place at An-Najah National University, where some of the lecturers are trained to visit other lecturers of their friends in the same faculty followed by writing a report that highlights strong and week points about the visited colleague. Through exchanging visits, lecturers can improve their teaching performance which in turns can improve students' achievement. According to Hay McBer (2000) suggested that 'star teachers' have knowledge and skills that can develop those who are lacking or have identified an area for their own improvement.

7.4.Academic Rank: the rank of a faculty member in a college or university, as professor, associate professor, assistant professor, or instructor.

\section{Literature Review}

A number of studies have dealt with teachers' personality and what good teachers' characteristics are .In this study the researcher refers to some studies related to the topic of this research. The researcher arranged similar studies chronologically from the most recent to the least 
Raymond, (2008) concluded that both faculty and students in the Gulf stated that effective university professor as a person who: (1) is appreciative, (2) makes classes interesting, (3) is fair (4) cares about students' success, (5) shows a love for their subject, (6) is friendly, (7) encourages questions and discussion, (8) is always well prepared and organized, and (9) simplifies their materials. Findings of students' and faculty's perspectives suggest that effective teaching is the blending of both personality and ability factors. The key factor, however, remains the teacher's personality. To some extent this agrees with Chickering and Gamson, 1991 and Hiebert \& Grouws, (2007) who argued that effective teachers have an impact on students' progress which could be looked upon as a relation between theory development and empirical work.

In the area of sharing students in teaching, Grzega, (2005) and Marion, (2007) overstressed learning by teaching and found out it is a widespread method in Germany where students take the teacher's role and teach their peers. This method is very effective when done correctly. Having students teach sections of the class as a group or as individuals is a great way to get the students to really study out the topic and understand it so as to teach it to their peers. By having them participate in the teaching process it also builds self-confidence, self-efficacy, and strengthens students speaking and communication skills. Students will not only learn their given topic, but they will gain experience that could be very valuable for life.

In regard to feedback and evaluation, some researchers believe that an effective teacher is who consistently achieves goals that are related either directly or indirectly to students' outcomes (Anderson, 2004; Sojka \& Deeter-Schmetz, 2002; Chen \& Hoshower, 2003). On the other hand other researchers Hativa, 1995; Gallagher, 2000Sojka, Gupta, \& Deeter-Schmetz, 2002 and Bain, 2004) showed that most faculties do pay attention to students' feedback. Instructors show a high degree of motivation to improve their teaching based on students' feedback. When faculty are well informed about the purposes of evaluation, much of their anxiety dissipates and willingness to learn from students' feedback increases.

Hobson \& Talbot, (2001) added in the area of evaluation and its importance saying that data used for evaluation should be decided by various stakeholders, including administrators, faculty and students, should collaborate in determining a proper evaluation system. Further, student rating data should be used in combination with other criteria in order to provide a better assessment of teaching, which is inherently a multidimensional construct.

Furthermore and in comparing between different forms of evaluation, Theall \& Franklin, (2001) indicated that mid-semester evaluations and feedback accompanied with consultation from a faculty developer or peer are more effective than traditional practices that leave the instructor to interpret end of semester findings by him/herself.

Another issues to consider is the correlation between organizing the material and effective teaching skills, where Lowman, 1996; McBer, 2000; Borich, 2000 and Day 2004 found out that an effective teacher is one who possesses competence in organizational skills such as systematizing materials in logical sequence with a high degree of clarity and presenting those materials in structured, step-by-step procedures. 
In the area of showing the relationship between grades and students' ratings, Marsh \& Roche, (1997) focused on the positive relationship between grades and students' ratings as a potential biasing factor. They said that the danger with this relationship is that it may encourage faculty to inflate their grades for the purpose of garnering higher ratings. Theories show that students infer course quality and own ability from received grades; students give high ratings in appreciation for lenient grades; and teaching effectiveness influences both grades and ratings. (Greenwald \& Gillmore, 1997a; McKeachie, 1997; Chambers \&Schmitt, 2002; Greenwald \& Gillmore, 1997).

From the previous literature review, it can be concluded that many researchers focused on the importance of teachers' efficiency in order to produce good quality teaching .For example: Raymond (2008); Anderson (2004); Hebert \& Grouws (2007). On the other hand, some of the previous literature dealt with students' evaluation and giving feedback on students' achievements .For example: Theal \& Franklin (2001); Hebson \& Talbat (2001); Sojka et al (2002). Furthermore, this study examined the impact of effective teaching strategies on producing good and fast learning outcomes from the lecturers' perspectives at An-Najah National University using variables which make it unique.

\section{Methodology}

This methodology deals with the sample and population of the study. Also it explores the description of instrument of the study and its significant differences, procedures, variables and statistical analysis.

\section{Population of the Study}

The population of the study consisted of all male and female lecturers at literary and scientific faculties at An-Najah National University.

\section{Sample of the Study}

The sample of the study consisted of eighth lecturer at An-Najah University. They were selected from four colleges ( 2 scientific and 2 literary) as follows:

Table1: Distribution of the study sample according to the independent variables

\begin{tabular}{|c|c|c|c|}
\hline Variables & Levels & Frequency & Percentage \\
\hline \multirow{3}{*}{ Place of graduation } & Inside Palestine & 2 & $\% 25.0$ \\
\hline & Arab countries & 3 & $\% 37.5$ \\
\hline & Foreign countries & 3 & $\% 37.5$ \\
\hline \multirow{2}{*}{ College } & Humanities & 4 & $50 \%$ \\
\hline & Applied Sciences & 4 & $50 \%$ \\
\hline \multirow{3}{*}{ Number of research } & Less than 5 & 2 & $25.0 \%$ \\
\hline & From 5-10 & $\overline{5}$ & $62.5 \%$ \\
\hline & More than 10 & 1 & $12.5 \%$ \\
\hline \multirow{2}{*}{$\begin{array}{lr}\text { Number } & \text { of } \\
\text { conferences } & \text { and }\end{array}$} & Less than 5 & 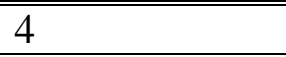 & $50.0 \%$ \\
\hline & From 5-10 & 2 & $25.0 \%$ \\
\hline
\end{tabular}




\begin{tabular}{|l|l|l|l||}
\hline workshops & More than 10 & 2 & $25.0 \%$ \\
\hline \hline \multirow{2}{*}{$\begin{array}{l}\text { Good Samaritan } \\
\text { program }\end{array}$} & Member & 4 & $50 \%$ \\
\cline { 2 - 4 } & Not a member & 4 & $50 \%$ \\
\hline \multirow{4}{*}{ Years of experience } & Less than 5 & 2 & $25.0 \%$ \\
\cline { 2 - 4 } & From 5-10 & 3 & $37.5 \%$ \\
\cline { 2 - 4 } & More than 10 & 3 & $37.5 \%$ \\
\hline \hline \multirow{3}{*}{ Academic rank } & Assistant professor & 3 & $37.5 \%$ \\
\cline { 2 - 4 } & Associate professor & 4 & $50 \%$ \\
\cline { 2 - 4 } & Full professor & 1 & $12.5 \%$ \\
\hline
\end{tabular}

\section{Instruments of the Study}

The researcher used a 25-item questionnaire to identify the teachers' responses towards the impact of effective teaching strategies on producing fast and good learning. The second tool of this study is a semi - structured interview which was designed by the researcher. It consists of three relevant questions

\subsection{Validity of the Tool}

To ensure the validity of the study tools the researcher gave them to a pair of judges: two specialists at An-Najah University. Their modification and recommendations were taken into consideration.

\subsection{Reliability of the Tool}

The researcher used Cronbach Alpha Formula to measure the internal consistency of the research tools which was (81.3).

\section{Variables of the Study}

This study includes the following variables:

Independent variables:

1) Place of graduation: (Inside Palestine, Arab countries or foreign countries).

2) College: (Humanities or applied sciences).

3) Number of research: (fewer than 5, from 5-10 or more than 10).

4) Conferences and workshops: (Less than 5, from 5-10 or more than 10).

5) Good Samaritan program: (member or not a member).

6) Years of experience: (fewer than 5, from 5-10 or more than 10).

7) Academic rank: (Assistant professor, Associate professor or full professor).

Dependent variable:

1) The impact of effective teaching strategies on producing good and fast learning outcomes. 


\section{Results and discussion}

This section presents the statistical data that have been analyzed using the SPSS statistical program. The data collected through the tool of the study represented by the questionnaire used to identify the impact of effective teaching strategies on producing good and fast learning outcomes.

\subsection{Results Related to Question (1) What is the Impact of Effective Teaching Strategies on Producing Good and Fast Learning Outcomes?}

In an attempt to answer this question, means, standard-deviations and percentages of each item were used, the researcher conducted the following levels to estimate the relation between computer and classroom interaction.

(80\%-100\%) very high.

(70\%- $79.9 \%)$ high.

(60\%- $69.9 \%)$ moderate.

(50\%- $59.9 \%)$ low.

(Less than $50 \%$ ) very low.

Table (2) shows the results.

Table 2: Means, standard deviations, percentages and degree of the items of the study tool

\begin{tabular}{|l|l|l|l|l|l|}
\hline NO & Item & Mean & $\begin{array}{l}\text { Standard } \\
\text { deviation }\end{array}$ & Percentage\% & $\begin{array}{l}\text { Level / } \\
\text { Degree }\end{array}$ \\
\hline 1. & $\begin{array}{l}\text { The teachers who graduate from national } \\
\text { universities have low effective teaching } \\
\text { strategies. }\end{array}$ & 3.53 & .830 & 70.6 & High \\
\hline 2. & $\begin{array}{l}\text { Teachers who graduated from foreign } \\
\text { universities have good and effective } \\
\text { teaching strategies. }\end{array}$ & 4.25 & 1.03 & $\begin{array}{l}\text { Very } \\
\text { high }\end{array}$ \\
\hline 3. & $\begin{array}{l}\text { The place of teacher graduation doesn't } \\
\text { affect his teaching strategies. }\end{array}$ & 3.51 & .92 & High \\
\hline 4. & $\begin{array}{l}\text { Teachers who graduated from Arab } \\
\text { countries universities have more effective } \\
\text { teaching strategies than teachers who } \\
\text { graduated from Palestinian universities. }\end{array}$ & 3.25 & 1.28 & Medium \\
\hline 5. & $\begin{array}{l}\text { Teachers who studied in humanistic } \\
\text { colleges have better teaching strategies. }\end{array}$ & 3.75 & 1.03 & 75.0 & High \\
\hline 6. & $\begin{array}{l}\text { The college where teacher had learnt } \\
\text { doesn't affect possessing effective } \\
\text { teaching strategies. }\end{array}$ & 3.65 & 1.28 & High \\
\hline 7. & $\begin{array}{l}\text { The college that the teacher studied in } \\
\text { increases the degree of possessing effective } \\
\text { teaching strategies. }\end{array}$ & 1.25 & 85.0 & Very \\
\end{tabular}




\begin{tabular}{|c|c|c|c|c|c|}
\hline 8. & $\begin{array}{l}\text { Teachers who studied in applied science } \\
\text { colleges possessing more effective } \\
\text { teaching strategies than who studied in } \\
\text { humanistic colleges. }\end{array}$ & 3.12 & 1.12 & 62.4 & Medium \\
\hline 9. & $\begin{array}{l}\text { The number of published researches } \\
\text { influence teachers' teaching strategies. }\end{array}$ & 4.21 & 1.35 & 84.2 & $\begin{array}{l}\text { Very } \\
\text { high }\end{array}$ \\
\hline 10. & $\begin{array}{l}\text { The teachers who published researches } \\
\text { have obtained good and effective teaching } \\
\text { strategies. }\end{array}$ & 4.25 & 1.03 & 85.0 & $\begin{array}{l}\text { Very } \\
\text { high }\end{array}$ \\
\hline 11. & $\begin{array}{l}\text { The teachers who published researches } \\
\text { periodically are possessing better teaching } \\
\text { strategies than who don't publish } \\
\text { researches. }\end{array}$ & 4.30 & .830 & 86.0 & $\begin{array}{l}\text { Very } \\
\text { high }\end{array}$ \\
\hline 12. & $\begin{array}{l}\text { The teachers who attended conferences and } \\
\text { workshops have good teaching strategies. }\end{array}$ & 4.25 & .700 & 85.0 & $\begin{array}{l}\text { Very } \\
\text { high }\end{array}$ \\
\hline 13. & $\begin{array}{l}\text { The number of attended conferences and } \\
\text { workshops don't influence teaching } \\
\text { strategies. }\end{array}$ & 2.55 & .530 & 51.0 & Low \\
\hline 14. & $\begin{array}{l}\text { Conferences and workshops are beneficial } \\
\text { and improve teachers' teaching strategies. }\end{array}$ & 3.56 & .640 & 71.2 & High \\
\hline 15. & $\begin{array}{l}\text { Teachers who participate in good } \\
\text { Samaritan program can improve their } \\
\text { teaching strategies. }\end{array}$ & 4.25 & 1.03 & 85.0 & $\begin{array}{l}\text { Very } \\
\text { high }\end{array}$ \\
\hline 16. & $\begin{array}{l}\text { The Samaritan program has no impact in } \\
\text { improving teaching strategies. }\end{array}$ & 3.25 & .880 & 65.0 & Medium \\
\hline 17. & $\begin{array}{l}\text { Teachers who participate more in the } \\
\text { Samaritan program can possess better } \\
\text { teaching strategies than who don't } \\
\text { participate. }\end{array}$ & 3.52 & 1.12 & 70.4 & High \\
\hline 18. & $\begin{array}{l}\text { The number of teachers' years of } \\
\text { experience has significant effects on } \\
\text { teachers' teaching strategies. }\end{array}$ & 4.27 & 1.12 & 85.4 & $\begin{array}{l}\text { Very } \\
\text { high }\end{array}$ \\
\hline 19. & $\begin{array}{l}\text { Teachers' years of experience affect the } \\
\text { quality of teaching strategies. }\end{array}$ & 4.32 & 1.30 & 86.4 & $\begin{array}{l}\text { Very } \\
\text { high }\end{array}$ \\
\hline 20. & $\begin{array}{l}\text { Early appointed teachers are possessing } \\
\text { effective teaching strategies better than } \\
\text { newly appointed teachers. }\end{array}$ & 4.30 & 1.41 & 86.0 & $\begin{array}{l}\text { Very } \\
\text { high }\end{array}$ \\
\hline 21. & $\begin{array}{l}\text { Years of experience has no effect on } \\
\text { possessing effective teaching strategies. }\end{array}$ & 3.75 & 1.03 & 75.0 & High \\
\hline 22. & $\begin{array}{l}\text { The teachers' academic rank has no effect } \\
\text { on possessing good teaching strategies. }\end{array}$ & 3.87 & .83 & 77.4 & High \\
\hline 23. & $\begin{array}{l}\text { The teachers whose academic rank is high } \\
\text { have better teaching strategies than low } \\
\text { academic rank teachers. }\end{array}$ & 3.57 & 1.12 & 71.4 & High \\
\hline
\end{tabular}




\begin{tabular}{|l|l|l|l|l|l|}
\hline 24. & $\begin{array}{l}\text { The academic rank have a positive effect } \\
\text { on possessing effective teaching strategies. }\end{array}$ & 3.87 & 1.24 & 77.4 & High \\
\hline 25. & $\begin{array}{l}\text { If the teacher has high academic rank this } \\
\text { doesn't mean that he possesses effective } \\
\text { teaching strategies. }\end{array}$ & 3.67 & 1.06 & 73.4 & High \\
\hline Total degree & 3.98 & .170 & 79.6 & High \\
\hline
\end{tabular}

Ten items have got very high degree. They are : 2,7,9,10,11,12,15,18,19 and 20 . Eleven items have got high degree. They are: $1,3,5,6,14,17,21,22,23,24$ and 25 . Three items have got medium degree. They are: 4, 8 and 16. Finally just one item has got low degree which is: 13 .

Table (2) illustrates that the degree of effective teaching strategies on producing good and fast learning outcomes are high and it demonstrates that the using of effective teaching strategies can enhance and increase the production of good and fast learning outcomes. These results are in accordance with Hiebert \& Grouws (2007); Grezega (2005) ; Anderson (2004) and Raba' and Hirzallah (2015) who argued that an effective has an impact on students' progress, so this proves that effective teaching strategies have a positive impact on producing good and fast learning outcomes.

\subsection{Results Related to Question (3)}

Are there statistical significant differences at $(\alpha=.05)$ between the teachers' responses about the impact of effective teaching strategies on producing fast and good learning outcomes due to the place of graduation?

To answer this question the researcher used one way ANOVA test, the results of the test shown in table (4) below.

Table 4: One Way ANOVA test

\begin{tabular}{|l|l|l|l|l|}
\hline $\begin{array}{l}\text { Place of } \\
\text { graduation }\end{array}$ & Means & $\begin{array}{l}\text { Standard } \\
\text { deviations }\end{array}$ & F & Significance \\
\hline Inside Palestine & 2.8800 & 28284. & & \\
\hline Arab countries & 2.8267 & 02309. & .223 & .8070 \\
\hline $\begin{array}{l}\text { Foreign } \\
\text { countries }\end{array}$ & 2.9333 & 23438. & & \\
\hline
\end{tabular}

Table (4) above shows that there are no statistical significant differences at $(\alpha=0.05)$ in the lecturers responses towards the impact of using effective teaching activities on producing good and fast learning outcomes due to the place of graduation. The researcher attributed this result to the fact that teaching strategies are almost similar for all the staff members except a little bit better in favor of those graduated from foreign countries. The education system and the way of being taught could be the reason behind this difference in the means. 
14.3. Results related to question (3): Are there statistical significant differences at ( $\alpha$ $=.05)$ in the impact of effective teaching strategies on producing fast and good learning outcomes due to the college he /she taught in ?

To answer this question Independent T-Test was used in order to identify the differences between the lecturers' responses towards the impact of effective teaching strategies.

Table 5: Independent T-Test

\begin{tabular}{|l|l|l|l|l|}
\hline College & Mean & Standard deviations & $\mathbf{t}$ & Significance \\
\hline Faculties of Human Sciences & 2.9120 & .21982 & & \\
\hline Faculties of Applied sciences & 2.8267 & .02309 & .649 & .540 \\
\hline
\end{tabular}

The results shown in table (5) above indicate that there are no statistical significant differences at $(\alpha=0.05)$ in the lecturers' responses towards the impact of effective teaching strategies on producing good and fast learning outcomes due to the college he /she taught in. The researcher attributed this result to almost similar teaching approaches followed by the different staff members. However, the differences in the means may be as a result of using more divergent teaching approaches by some of the staff members in the faculties of human sciences and this can be attributed to the staffs' more exposure to educational theories and pedagogies more than their colleagues in the faculties of applied sciences

\subsection{Results related to question ( 4 ): Are there statistical significant differences at ( $\alpha$ $=.05$ ) in the impact of effective teaching strategies on producing fast and good learning outcomes due to the number of research ?}

To answer this question the researcher used one Way ANOVA test and the table below show the results.

Table 6: One Way ANOVA Test

\begin{tabular}{|l|l|l|l|l|}
\hline Number of research & Means & Standard deviations & F & Significance \\
\hline Less than 5 & 2.9400 & 36770. & \multirow{3}{*}{127.} & \multirow{2}{*}{.883} \\
\cline { 1 - 3 } From 5-10 & 2.8640 & 12522. & & \\
\hline More than 10 & 2.8400 & .1242 & \\
\hline
\end{tabular}

The above table reveals that there were no statistical significant differences at $(\alpha=0.05)$ in the participants' responses towards the issue of the impact of effective teaching strategies on producing good and fast learning outcomes due to the number of research variable. The researcher attributed this results to that not all the researchers directed towards teaching strategies issue, they may deal with different issues which do not help in improving teaching strategies. 
14.5. Results related to question (5): Are there any statistical significant differences at ( $\alpha$ $=.05)$ in the impact of effective teaching strategies on producing fast and good learning outcomes due to the number of conferences and workshops?

To answer this question the researcher used one Way ANOVA Test, the results shown in table (7) bellow.

Table 7: One Way ANOVA Test

\begin{tabular}{|l|l|l|l|l|}
\hline Number of conferences & Means & Standard deviations & F & Significance \\
\hline Less than 5 & 2.8800 & .22390 & \multirow{3}{*}{1.932} & \multirow{2}{*}{.239} \\
\hline From 5-10 & 2.8400 & .00000 & & \\
\hline More than 10 & 2.9200 & .22627 & \\
\hline
\end{tabular}

The results of this question shows that there were no statistical significant differences at $(\alpha=0.05)$ in the responses on the impact of effective teaching strategies on producing good and fast learning outcomes due to the number of conferences and workshops variable. This result may be attributed to the fact that the staff members who participate more conferences or workshops use somehow better and more effective teaching strategies that help learners learn better and faster.

14.6. Results related to question (6): Are there any statistical significant differences at ( $\alpha$ $=.05$ ) in the impact of effective teaching strategies on producing fast and good learning outcomes due to the membership in good Samaritan program?

To answer this question the researcher used Independent T-Test, the following table shows the results.

Table 8: Independent T-Test

\begin{tabular}{|l|l|l|l|l|}
\hline Good Samaritan program & Mean & Standard deviations & t & Significance \\
\cline { 1 - 4 } Member & 2.9000 & .20265 & .306 & .770 \\
\hline Not a member & 2.8600 & .16492 & & \\
\hline
\end{tabular}

The results indicate that there were no statistical significant differences at $(\alpha=0.05)$ in the responses of the impact of effective teaching strategies on producing good and fast learning outcomes due to membership in Good Samaritan program variable .The researcher attributed this results to the fact that to be a member of the Samaritan program or not to be a member will not affect the lecturers' attitudes towards the effectiveness of the impact of effective teaching strategies on producing good and fast learning outcomes. Nevertheless, the difference in the means in favor of those who are members in the program simply means that the members use better teaching strategies and thus affect students' learning better. 
14.7. Results related to question (7): Are there any statistical significant differences at ( $\alpha$ $=.05)$ in the impact of effective teaching strategies on producing fast and good learning outcomes due to years of experience?

To answer this question the researcher used one Way ANOVA Test, the results shown in the table below.

Table 9: One Way ANOVA Test

\begin{tabular}{|l|l|l|l|l|}
\hline Years of experience & Means & Standard deviations & F & \multirow{2}{*}{ Significance } \\
\cline { 1 - 3 } Fewer than 5 & 2.7600 & .11314 & \multirow{2}{*}{.645} & \multirow{2}{*}{.563} \\
\cline { 1 - 3 } $5-10$ & 2.9467 & .22030 & & \\
\hline More than 10 & 2.8933 & .16653 & \\
\hline
\end{tabular}

The results shown in the above table show that there were no statistical significant differences at $(\alpha=0.05)$ in the attitudes towards the impact of effective teaching strategies on producing good and fast learning outcomes due to years of experience. The differences in the means in regard to years of experience are interpreted as follows: Those who have less than five receive the lowest mean due to lacking of experience where as those who have from five to ten receive the highest mean which shows that they have experience and enthusiasm as well while those whose experience is more than ten start to faint and lose enthusiasm.

14.8. Results related to question (8): Are there any statistical significant differences at ( $\alpha$ $=.05$ ) in the impact of effective teaching strategies on producing fast and good learning outcomes due to academic rank?

In order to answer this question the researcher used one Way ANOVA Test. The results are shown in table (10).

Table 10: One Way ANOVA Test

\begin{tabular}{|l|l|l|l|l|}
\hline Academic rank & Means & Standard deviations & F & Significance \\
\hline Assistant professor & 2.9867 & .2722 & & \multirow{2}{*}{.906} \\
\hline Associate professor & 2.8100 & .0383 & .462 \\
\hline Full professor & 2.8400 & & \\
\hline
\end{tabular}

Also the results of this question show that there were no statistical significant differences at $(\alpha=0.05)$ in the attitudes of the impact of effective teaching strategies on producing good and fast learning outcomes due to academic rank variable. The researcher attributed this result to the fact that no one can deny the importance of effective teaching activities to produce effective learning outcomes.

\section{Results Related to the Second Tool of the Study}

The interview is a kind of qualitative method of research which supports and strengthens the theoretical data. The interview consists of three questions as follow: 
1) Do you support using effective teaching strategies in the teaching - learning process?

2) Do you believe that the use of effective teaching strategies will influence the learning outcomes?

3) Based on your experience, what do you suggest for improving effective teaching strategies?

In regard to the first two questions, the five lecturers strongly support the use of effective teaching strategies on producing good and fast learning outcomes. Also they encourage the lecturers to vary teaching strategies for the learners to choose the activities that suit their abilities.

In regard to the third question, the lecturers suggest attending workshops and conferences to share other lecturers' teaching strategies and also to develop their own strategies and to have an eye on what is new in the field of teaching strategies.

\section{Conclusion and Recommendations}

Teaching strategies, like all the other materials, activities and resources we provide to learners to make them good learners. Providing learners with effective and good teaching strategies will endowed the learners with a variety of activities they can choose from what is suitable for their abilities and interests.

The researcher comes to conclusion that is: Good and fast learning outcomes is the ultimate goal that teachers and learners are seeking to achieve. This study examined the impact of effective teaching strategies on producing good and fast learning outcomes. The study revealed that there is a positive impact of effective teaching strategies on producing good and fast learning outcomes. The study shows that there were no statistical significant differences at $(\alpha=0.05)$ in the lecturers attitudes towards the impact of using effective teaching strategies on producing good and fast learning outcomes.

The researcher comes to another conclusion that effective teaching strategies have a positive impact on producing good and fast learning outcomes. It would be more helpful to consider teaching strategies as an aid to the teacher just like any other teaching aid. That is to say, effective teaching strategies can offer the teacher much more to enhance and support students' learning.

In closing teachers should not neglect the importance of effective teaching strategies in the teaching-learning process. They help offering the teacher and the learner with aids to produce effective learning outcomes. Based on the results of the study the researcher recommended the following:

- Lecturers should use a variety of teaching strategies to choose the best for the topic they are going to teach.

- Lecturers should develop their teaching strategies because the world is developing every day.

- Lecturers should use teaching strategies that interest the learners and get them involved. 
- Lecturers should take into account learners individual differences when choosing the suitable teaching strategies.

- Conduction other studies that deal with the same topic but from the learners' perspectives.

\section{References}

[1] Anderson, L.W. (2004). Increasing teacher effectiveness. 2nd edition. Paris: IIEP-UNESCO http://www.unesco.org/iiep.

[2] Angelo, T., \& Cross, K. P. (1993). Classroom assessment techniques: A handbook for college teachers. San Francisco: Jossey-Bass.

[3] Bain, K. 2004. What the Best College Teachers Do. Cambridge, MA: Harvard Press.

[4] Beishuizen, J; Hof, E.; Putten, C; Bouwmeester, S and Asscher, J.(2001) Students' and teachers' cognitions about good teachers. British Journal of Educational Psychology, 71(2), 185-201.

[5] Borich, G. D. (2000). Effective teaching methods. New Jersey: Prentice-Hall.

[6] Brookfield, S. D. (1995). Becoming a critically reflective teacher. San Francisco: Jossey-Bass.

[7] Chen, Y. \& Hoshower, L.B. 2003. "Student evaluation of teaching effectiveness: an assessment of student perception and motivation." Assessment and Evaluation in Higher Education 28(1): $71-88$

[8] Chickering, A., \& Gamson, Z. (1987). Seven principles of good practice in undergraduate education. AAHE Bulletin, 39, 3-7.

[9] Day, C. (2004). A Passion for Teaching. London: Routledge Falmer.

[10] Eble, K. (1988). The craft of teaching (2nd ed.). San Francisco: Jossey-Bass.

[11] Gallagher, T.G. 2000. "Embracing student evaluations of teaching: a case study." Teaching Sociology 28, 140-147

[12] Gatto, John Taylor. (2000). A Different Kind of Teacher: Solving the Crisis of American Schooling. Reflections on the bitter lessons of the American Systems. Berkeley Hills Books. ISBN 1-893163-21-0.

[13] Graham, C., Cagiltay, K., Craner, J., Lim, B., \& Duffy, T. M. (2000). Teaching in a Web-based distance learning environment: An evaluation summary based on four courses. Centre for Research on Learning and Technology Technical Report No. 13-00. Indiana University Bloomington. Retrieved September 18, 2000 from the World Wide Web: http://crlt.indiana.edu/publications/crlt00-13.pdf

[14] Grasha, A. (1996). Teaching with style: A practical guide to enhancing learning by understanding teaching and learning styles. Pittsburgh: Alliance.

[15] Grzega, Joachim and Schoener, Marion. (2007)"The Didactic Model LdL (Lernendurch Lehren) as a Way of Preparing Students for Communication in a Knowledge Society." Journal of Education for Teaching 34 (3): 167-175

[16] Grzega, Joachim (2005a), "Learning by Teaching: The Didactic Model LdL in University Classes,"http://www.grzega.deorhttp://www.ldl.de/ material/berichte/uni/uni.htm.

[17] Hay McBer (2000). Research into Teacher Effectiveness: A Model of Teacher Effectiveness. A report by Hay McBer to the Department of Education and Employment, United Kingdom.

[18] Hativa, N. 1995. "The department-wide approach to improving faculty instruction in higher education: a qualitative evaluation." Research in higher education 36(4): 377-413.

[19] Hiebert, J. \& Grouws, D. (2007). The Effects of Classroom Mathematics Teaching on Students' Learning. In Lester, F.K., Second Handbook of Research on Mathematics Teaching and Learning (371-404). New York: MacMillan.

[20] Hoyt, D.P. \&Pallett, W. H. 1999. "Appraising teaching effectiveness: beyond student ratings." IDEA Paper \# 36 
[21] Hobson, S. M. \& Talbot, D. M. 2001. "Understanding student evaluations: what all faculty should know?" College Teaching 49(1): 26-31

[22] Hoyt, D.P. \&Pallett, W. H. 1999. "Appraising teaching effectiveness: beyond student ratings." IDEA Paper \# 36

[23] Johnson \& Ryan 2000. "A comprehensive approach to the evaluation of college teaching." New Directions for Teaching and Learning, no.83. Fall 2000

[24] Jossey-Bass, (2004) Teacher Leadership. Teaching Methods: Demonstrations. National Board Certified Digital Edge Teachers. Lieberman, Ann. California. USA

[25] Kulik, J.A. 2001. "Student ratings: validity, utility, and controversy." New Directions for Institutional Research 109, 9-25.

[26] McKeachie, W. 1997. "Student ratings; the validity of use." American Psychologist v52, no.11, 1218-1225.

[27] McKeachie, W. and Svinicki, M. 2006. McKeachie's. Teaching Tips. Boston, MA: Houghton Mifflin Company

[28] Ory, J. 2000. "Teaching evaluation: past, present, and future." New Directions for Teaching and Learning, no.83, Principles for good practice in undergraduate education: Faculty inventory. (1989). Racine, WI: The Johnson Foundation, Inc.

[29] Raba, A. A. A. M. \& Harzallah, H. T. M. (2015). Effective teaching from An-Najah National University M.A. Students' perspectives. Journal of Languages and Culture, 6(6), 52 - 60.

[30] Raymond, S. Marguerite. (2008) Effective and Ineffective University Teaching from the Students' and Faculty's Perspectives: Matched or Mismatched Expectations? Unpublished Ph.D Dissertation. University of Exeter.

[31] Siegel, E (1975). Good Will Is Aesthetics. In The Right of Aesthetic Realism to Be Known, issue no. 121,23

[32] Sojka, J., Gupta, A.K. \& Deeter-Schmetz, D.R. 2002. "Student and faculty perception of student evaluations of teaching: a study of similarities and differences." College Teaching 50(2): 44-49.

[33] Theall, M. \& Franklin, J. 2001. "Looking for bias in all the wrong places: a search of truth or a witch hunt in student ratings of instruction?" New Directions for Institutional Research 109: 4556.

[34] Villegas-Reimers, E. (2003). Teacher Professional Development: an international review of the Literature. Paris: IIEP-UNESCO.

[35] Walls, R.T., Nardi, A. H., von Minden, A.M., \& Hoffman, N. (2002). The characteristics of effective and ineffective teachers. Teacher Educational Quarterly, winter, 29(1), 39-48.

[36] Weimer, Maryellen (2013) Essential Teaching Principles: A Resource Collection for Adjunct Faculty. Magna Publications. 2718 Dryden Drive. Madison. WI53704. Magnaub.com

\section{About Author}

Raba' AAA was employed in English teaching in Saudi Arabia and Jordan for many years before moving to Palestine to work as a teacher of English, a supervisor of English and employed in different positions at An-Najah National University. He has published studies in the field of pedagogy $\{$ TEFL $\}$ and the related areas. He is now a staff member in the Faculty of Education and Teacher Training and Post Graduate Faculty.

*Corresponding author.

E-mail address: ahmedm@najah.edu 